\section{Complementary}

Medicine Research

Practice $\mid$ Methods|Perspectives

\section{Editorial}

Complement Med Res 2018;25:4-6 DOI: $10.1159 / 000486887$
Published online: February 26, 2018

\title{
Good Morning Future: Complementary Medicine's Next 25 Years
}

\author{
Harald Walach \\ Department of Pediatric Gastroenterology, Medical University Poznan, Poznan, Poland
}

When we launched our journal COMPLEMENTARY MEDICINE RESEARCH a quarter of a century ago as FORSCHENDE KOMPLEMENTÄRMEDIZIN, our field was small. We were a couple of research activists meeting in the late Steven Karger's office in Basel. My vote for an English title, already then, was overruled with the argument that most research was happening in the German-speaking countries anyway, a point which was difficult to counter at the time, in 1992. At the same time, and without any one of us knowing this, senator Tom Harkin and congressman Berkley Bedell started political moves to open the Office of Alternative Medicine (OAM) in the USA, which became the National Center for Complementary and Alternative Medicine (NCCAM) in 1995 [1]. Starting with just a few million USD, its budget became comparatively large amounting to 120-150 million USD over the years. As is often the case, once the colleagues in the USA understand that something is important and open the political arena for it, they do it more consequently than us in Europe. Academic centers opened their doors for research, patient care, and training of students and doctors. What is called Integrative Medicine (IM) nowadays - the integration of wellresearched and proven methods into conventional care -, is available in almost all reputable American medical schools, and 72 institutional members make up the Academic Consortium for Integrative Medicine and Health (www.imconsortium.org/about/factsheet.cfm). The next conference of the Consortium in conjunction with the International Society for Complementary Medicine Research (ISCMR; www.iscmr.org) in Baltimore, MD, in May 2018 (https://internationalcongress.imconsortium.org) will bring together at least 1,000 researchers from all over the globe. Had anyone told us this at our first brainstorming meeting in Steven Karger's office, we would have laughed heartily.

Complementary and Alternative Medicine (CAM) or IM has become a serious player, both in the scientific field and on the market. One of the major accomplishments of joint research efforts was the grudging acceptance of acupuncture into health care systems across the Western world $[2,3]$. The US military uses it for acute-pain control, the US academic centers offer it in their portfolio, even the German statutory reimbursement system pays for it. Another highlight is the mutation of placebo research into a mainstream effort of considerable impact. This was fueled by a conference organized at the OAM in 1995 and a call for proposals by the NCCAM following this meeting. The insight of how important so-called non-specific therapeutic effects can be, and that they should rather be called selfhealing responses [4-6], is genuinely derived from CAM research. Attempting to understand how acupuncture and manual therapy works has prompted various researchers to study the connective tissue and the extracellular matrix [7-9], an area that has always been in the focus of holistic researchers, especially in Germany $[10,11]$.

\section{KARGER}

() 2018 S. Karger GmbH, Freiburg

Fax +497614520714
Harald Walach, $\mathrm{PhD}$

Department of Pediatric Gastroenterology

Medical University Poznan

ul. Szpitalna 27/33, 60-572 Poznan, Poland

hwalac@gmail.com 
Just recently a US market research organization (www.transparencymarketresearch.com/sample/sample.php?flag = Serrep_id = 16460) produced a forecast saying that the market for homeopathic products will grow rapidly from 386 million USD in 2015 to 17 billion USD in 2024 (reported by the European Committee on Homeopathy; https://homeopathyeurope.org/global-demand-homeopathyforecast-surge). Although Europe is going to remain an important market, the major growth will happen worldwide, in Asia Pacific, Africa, North and South America. This, mind you, is only pertaining to homeopathy. Phytotherapy, Chinese Herbal Medicine, or Ayurveda are not even covered here. This rise, the report stated, is based on various factors: the status that homeopathy (and CAM in general) is carving out for itself in the markets and the favor of health care consumers in Europe and the USA. This favor, in turn, is due to the fact that conventional treatment options are very often fraught with side effects and much more expensive, or they produce public-health problems such as opiate dependency in pain sufferers and rising antimicrobial resistance through inadequate application. While conventional treatments of upper respiratory tract infections in children are still and against better evidence often contributing to the resistance problematic by using antibiotics, homeopathic or other CAM alternatives are available which are associated with good experiences [12]. In the USA, the integration of acupuncture and other CAM pain treatments into conventional programs was largely driven by the huge dependency problem caused by the overprescription of opiates.

The number of consumers of homeopathy in the UK has remained stable and is forecast to rise, despite the fact that hefty public campaigns in UK media and newspapers have attempted to 'educate' the public about the lack of scientific foundation of homeopathy. An overview of 16 surveys from the last couple of years showed that, at least in Germany, the number of doctors using CAM is on the rise, even though the numbers of patients who ask for CAM seem to be slightly dropping [13]. But on the whole, Europe, together with the USA, is driving the international interest in homeopathy, as the Transparency Market Research Report states. Might it be the case that this bland fact is the catalyst for continuous attacks against CAM in general and homeopathy in particular in mainstream media and on skeptical blogs? To put it bluntly: Might it be the case that 'big pharma' is getting nervous about future revenues and pulling some levers, making some phone calls to lobbyists and journalists, briefing some communication agencies? In the light of the fact that some simple, old medical advice is being studied and found effective, such as honey for wound healing [14], or that a dietetic approach to cancer care such as ketogenic diet is increasingly researched and offered even by mainstream medical institutions $[15,16]$, following the demand of patients, the death knell for CAM sounded by mainstream journalists and researchers can only be attributed to the new rubric of 'fake news'.

The economic future for CAM is bright, it seems. The political reaction in Germany and Europe is lagging behind though. As we have often demanded $[17,18]$, the adequate and obvious political reaction should be publicly supported research programs, ideally in the form of a European research institute or, failing this, national dedicated public research programs. It is a political scandal that on the one hand more than half of the German population is using CAM approaches such as homeopathy, and on the other hand regulatory bodies, critical and other researchers, politicians, and the media lament about the lack of scientific evidence. Who, if not public funders, should have the monetary stamina and the political interest to serve the public demand?

However, so far, a small group of dedicated researchers has managed - by attracting charitable money or funding from insurance companies and, in rare cases and through self-sacrificing rituals of multiple submissions, from public sources - to bring CAM to the scientific agenda, where it has not only remained but achieved considerable success. So we can expect that there will be more to come. The economic prospects for CAM, as is always the case, will also generate research requests. This might finally lead to the necessary moves: public research money, universities opening their gates not only to the money that comes with CAM research but also to the necessity of looking into the matter more deeply, offering career tracks to young researchers and positions to senior ones, even in Europe.

The most important move, though, that needs to happen over the next quarter of a century is a critical reflection and the integration of paradigmatic foundations of some CAM systems, and not only their procedures, where useful, into conventional treatment concepts. This will lead to a silent revolution that is already appearing on the horizon. Systems biology has started to question the mechanistic outlook of molecular biology that is still the major driver of medical innovation [19-23]. Serious voices within biology are casting doubt on the mainstream dogma according to which things, like molecules and cells, are the basis of life. Rather, they state, we need to focus on the complementarity of processes and structures following from processes [24]. This is very close to fundamental tenets of complementary practitioners [25].

Our journal has always been at the forefront of this movement $[26,27]$, and will continue to be so. Thus, COMPLEMENTARY MEDICINE RESEARCH will remain a forerunner and seismograph of future changes. Therefore, we will keep publishing challenging theoretical essays that describe important theoretical developments. We will continue to give space to novel treatments [28] even if they are not yet 'evidence-based' and studied in randomized trials. Everything that is evidence-based today was once innovative, incredible, or impossible - we are the ones who help making it possible. We will continue to be the spearhead of the movement that drives our medical system, patient care, research, and practice towards a more humane, more affordable, less risky, and more holistic enterprise. Welcome to the future. It started 25 years ago.

\section{Disclosure Statement}

I have no conflict of interest except the intellectual one that I am quite sure our medical system needs to open up to CAM approaches in research and practice in order to meet the challenges. I have published books on this issue that are a small source of income. 


\section{References}

1 Jonas WB, Eisenberg D, Hufford D, Crawford C: The evolution of complementary and alternative medicine (CAM) in the USA over the last 20 years. Forsch Komplementmed 2013;20:65-72.

2 Su LJ, Meng L, Chen R, Wu W, Peng B, Man L: Acupoint application for asthma therapy in adults: a systematic review and meta-analysis of randomized controlled trials. Forsch Komplementmed 2016;23:16-21.

3 Vickers AJ, Cronin AM, Maschino AC, Lewith GL, MacPherson H, Foster NE, Sherman KJ, Witt CM, Linde K; Acupuncture Trialists' Collaboration: Acupuncture for chronic pain: individual patient data meta-analysis. Arch Intern Med 2012;172:1444-1453.

4 Walach H: Der Minderwertigkeitskomplex der Psychotherapie oder die Frage nach dem Placebo: Einige kriti sche Gedanken zur derzeitigen Diskussion. Verhaltenstherapie 2017;27:53-56.

5 Walach H: Reconstructing the meaning effect - the capacity to self-heal emerges from the placebo concept. Tidsskrift for Forskning i Sygdom og Samfund 2015;23: 111-139.

6 Walach H: The efficacy paradox and its consequences for research in psychotherapy (and elsewhere). Psycho Conscious (Wash D C) 2016;3:154-161.

7 Langevin HM, Keely P, Mao J, Hodge LM, Schleip R, Deng G, Hinz B, Swartz MA, de Valois BA, Zick S Findley T: Connecting (t)issues: how research in fascia biology can impact integrative oncology. Cancer Res 2016;76:6159-6162.

8 Langevin HM, Nedergaard M, Howe AK: Cellular control of connective tissue matrix tension. J Cell Biochem 2013;114:1714-1719.

9 Bordoni B, Marelli F: Emotions in motion: myofascia interoception. Complement Med Res 2017;24:110-113.

10 Pischinger A: Das System der Grundregulation: Grundlagen einer ganzheitsbiologischen Medizin. Stuttgart Karl F. Haug Verlag, 2004.
11 Heine $\mathrm{H}$, Anastasiades P (eds): Normal Matrix and Pathological Conditions. Stuttgart, Fischer, 1992.

12 Thinesse-Mallwitz M, Maydannik V, Keller T, Klement P: A homeopathic combination preparation in the treatment of feverish upper respiratory tract infections: an international randomized controlled trial. Forsch Komplementmed 2015;22:163-170.

13 Linde K, Friedrichs C, Alscher A, Wagenpfeil S, Meissner K, Schneider A: The use of placebo and non-specific therapies and their relation to basic professional attitudes and the use of complementary therapies among German physicians - a cross-sectional survey. PLoS One 2014;9:e92938.

14 Goharshenasan P, Amini S, Atria A, Abtahi H, Khorasani G: Topical application of honey on surgical wounds: a randomized clinical trial. Forsch Komplementmed 2016;23:12-15.

15 Klement RJ: Fasting, fats, and physics: combining ketogenic and radiation therapy against cancer. Complement Med Res 2017;DOI: 10.1159/000484045.

16 Jansen N, Walach H: The development of tumours under a ketogenic diet in association with the novel tumour marker TKTL1: a case series in general practice. Oncol Lett 2016;11:584-592.

17 Weidenhammer W, Lewith G, Falkenberg T, Fønnebø V, Johannessen H, Reiter B, Uehleke B, von Ammon K, Baumhöfener F, Brinkhaus B: EU FP7 project 'CAMbrella' to build European research network for complementary and alternative medicine. Forsch Komplementmed 2011;18:69-76.

18 Walach H, Pietikäinen S: A roadmap for CAM research towards the horizon of 2020. Forsch Komplementmed 2014;21:80-81.

19 Pezzulo G, Levin M: Re-membering the body: applications of computational neuroscience to the top-down control of regeneration of limbs and other complex organs. Integr Biol (Camb) 2015;7:1487-1517.
20 Hankey A: A new approach to biology and medicine: an expanded role for regulation. Journal of the Science of Healing Outcomes 2015;7:13-18.

21 Capra F, Luisi PL: The Systems View of Life: A Unifying Vision. Cambridge, Cambridge University Press, 2014.

22 Schroën $Y$, van Wietmarschen HA, Wang M, van Wijk EPA, Hankemeier T, Xu G, van der Greef J: East is East and West is West, and never the twain shall meet? Science 2014;346:S10-S12.

23 van der Greef J, van Wietmarschen H, Schroën J, Wang M, Hankemeier T, Xu G: Systems biology-based diagnostic principles as pillars of the bridge between Chinese and Western medicine. Planta Med 2010;76:20362047.

24 Dupré J, Nicholson DJ: Towards a processual philosophy of biology; in Nicholson DJ, Dupré J (eds): Everything Flows: Towards a Processual Philosophy of Biology. Oxford, Oxford University Press, 2018 (in print).

25 Ofner M, Kastner A, Schwarzl G, Schwameder H, Alexander N, Strutzenberger G, Walach H: RegentK and physiotherapy support knee function after anterior cruciate ligament rupture without surgery after 1 year: a randomized controlled trial. Complement Med Res 2017;DOI: $10.1159 / 000479152$

26 Walach H, Pincus D: Kissing Descartes good bye. Forsch Komplementmed 2012;19(suppl 1):1-2.

27 Pincus D, Walach H (eds): Complexity, Whole Systems Research, and Complementary Therapies: New Concepts and Methods. Freiburg, Karger, 2012.

28 Mangelsdorf I, Walach H, Mutter J: Healing of amyotrophic lateral sclerosis: a case report. Complement Med Res 2017;24:175-181. 